\title{
Analisis Perbandingan Mazhab tentang Pelaksanaan Mediasi Dengan Media Telekonferensi
}

\author{
Nurul Aulia Dewi dan Abd. Halim Talli \\ Universitas Islam Negeri Alauddin Makassar \\ nurulaulia27111999@gmail.com
}

\begin{abstract}
Abstrak
Artikel ini berupaya untuk memaparkan perbandingan mediasi dengan media telekonfrensi, baik dalam PERMA maupun para pendapat ulama mazhab. Mediasi merupakan upaya penyelesaian konflik dengan melibatkan mediator yang netral yang tidak memiliki kewenangan mengambil keputusan yang membantuk pihak - pihak yang bersengketa untuk mencapai peneyelsaiaan atau solusi yang di terima kedua belah pihak. Pendekatan multidisipliner yang digunakan dalam artikel ini, yaitu pendekatan yuridis, sosilogis, teologis-normatif dan pendekatan manajerial. Artikel ini penelitian pustaka (Library Research), yakni suatu penelitian dengan cara menuliskan, mengklarifikasi, dan menjadikan data yang diperoleh dari berbagai sumber tertulis. Adapun metode pengumpulan data yaitu menggunakan teknik dokumen (studi pustaka). Mengutip dan menganalisis data dengan teknik dokumen dimaksudkan untuk mengumpulkan data terkait yang dimuat dalam dokumen-dokumen berupa buku-buku, jurnal, dan hasil penelitian berupa skripsi, tesis, dan disertasi. Hasil penelitian menemukan bahwa perbedaan yang paling menonjol mengenai batas mediasi dengan media teleconference yaitu terdapat pada perbedaan pendapat para ulama Mazhab. Mazhab Syafi' dan Hanbali berpendapat bahwa usia ideal dalam pernikahan ialah 15 tahun, sedangkan Abu Hanifah berpendapat bahwa usia kedewasaan datang pada saat umur 19 tahun bagi perempuan dan 17 tahun bagi laki-laki, lain halnya dengan Imam Malik berpendapat bahwa usia ideal kedewasaan yaitu 18 tahun baik bagi laki-laki maupun perempuan. Perbedaan para Imam Mazhab tersebut dipengaruhi oleh lingkungan dan kultur di tempat mereka tinggal. Namun, dalam hukum Islam sendiri tidak pernah member batasan yang sangat tegas, tetapi hal yang paling mendasar mengenai batas usia pernikahan ialah sudah balig.
\end{abstract}

Kata Kunci: Mediai; Media Teleconference; Pandangan Ulama Mazhab.

\begin{abstract}
This article seeks to present a comparison of mediation with teleconference media, both within the PERMA and the scholars of the sect. Mediation is an attempt to resolve conflicts by engaging neutral mediators who do not have the authority to make decisions that help the parties in dispute to reach a resolution or solution accepted by both parties. The multidisciplinary approach used in this article is a juridical, sociological, theological-normative and managerial approach. This article is library research, a study by writing, clarifying, and making data obtained from various written sources. The method of data collection is to use document techniques (library studies). Quoting and analyzing data with document techniques is intended to collect related data contained in documents in the form of books, journals, and research results in the form of thesis, thesis, and dissertation. The results found that the most notable differences regarding the limits of mediation with teleconference media were found in the dissent of the Sect scholars. The Shafi and Hanbali sects argue that the ideal age in marriage is 15 years, while Abu Hanfah argues that the age of maturity comes at 19 years of age for women and 17 years for men, as is the case with Imam Malik arguing that the ideal age of manhood is 18 years for both men and women. The differences between the Imams of the Sect are influenced by the environment and culture in which they live. However, in Islamic law itself there is never a very firm limit, but the most basic thing about the age limit of marriage is that it is already in place.
\end{abstract}

Keywords: Mediation; Teleconference media; Views of school scholars. 


\section{Pendahuluan}

Era saat ini, segala sesuatu dapat dengan mudah kita selesaikan dengan cara yang mudah dan atau praktis. ${ }^{1}$ Hal tersebut merupakan salah satu dampak dari hadirnya tehnologi, tehnologi komunikasi adalah system elektronik yang digunakan untuk berkomunikasi antara individu ataupun kelompok.

Kemajuan ilmu dan tehnologi yang semula bertujuan untuk memudahkan pekerjaan manusia tetapi kenyataan tehnologi telah menimbulkan keresahan dan ketakutan baru bagi kehidupan manusia. Kekuatan yang dirasakan oleh manusia akibat perkembangan tehnologi ini disebabkan adanya penyalagunaan oleh orang-orang yang tidak bertanggungjawab. ${ }^{2}$ Perkembangan tehnologi semakin pesat, selain penemuan-penemuan dibindang kedokteran, kimia, dan fisika, telah banyak pula ditemukan tehnologi baru yang tidak kalah pentingnya dibidang komunikasi. Salah satunya adalah mediasi teleconference (jarak jauh). Dengan adanya mediasi teleconference menuai banyak kontroversi baik dikalangan pemerintah maupun masyarakat.

Keberadaan hukum dengan masyarakat merupakan suatu kesatuan yang tidak dapat dipisahkan, hukum timbul karena adanya interaksi antara individu di masyarakat maupun antar masyarakat lainnya. Dari interaksi-interaksi tersebut di masyarakat lainnya.Dan interaksi-interaksi di masyarakat tersebut muncul norma, norma merupakan suatu aturan dimana manusia sebagai individu dalam perilaku terhadap individu lain maupun masyarakat agar kepentingan orang lain terganggu atau berbenturan. Norma memiliki hubungan dengan kaidah hukum, kaidah hukum merupakan peraturan hidup yang menentukan bagaimana manusia itu sepantasnya berperilaku.

Manusia adalah mahkluk sosial (zoon politikon) makhluk yang tidak dapat melepaskan diri dari berhubungan atau berinteraksi dengan manusia lain untuk memenuhi kebutuhan hidup, baik jasmani maupun rohani. Dalam melaksanakan aktivitas hubungan

1 Wahyuddin Naro et al., "Shariah Assessment Toward the Prosecution of Cybercrime in Indonesia," International Journal of Criminology and Sociology 9 (2020): 572-86, https://doi.org/https://doi.org/10.6000/1929-4409.2020.09.5.

2 Abdul Syatar and Achmad Abubakar, Filosofi 'Uqubah Islamiyah Versi Ramadhan Al-Buti; Relevansi Dengan Pemidanaan Dalam Sistem Hukum Indonesia (Gowa: Alauddin University Press, 2020). 
sosial antar manusia tentu saja akan terdapat dinamika berupa persamaan maupun perbedaan. Persamaan tentu saja akan menambah eratnya relasi antar manusia adapun pebedaan akan melahirkan beberapa konflik antar manusia. ${ }^{3}$

Sengketa atau konflik yang tidak berkelolah dengan baik bisa mengarahkan pihak yang bersengketa mengambil nalar sendiri-sendiri dalam menyelesaikanya. Keduanya (sengketa atau konflik) merupakan konsep yang sama mendiskripsikan situasi dan kondisi di mana seseorang yang mengalami perselisihan yang bersifat factual maupun perselisihan-perselisihan yang ada pada persepsi mereka saja. ${ }^{4}$ Dari pengertian tersebut secara umum konflik atau sengketa disebabkan oleh masalah-masalah factual seperti masalah yang konkret terjadi di masyarakat, maupun sebab yang lebih abstrak yaitu persepesi atau pandangan seseorang.

Ketika konflik ataupun sengketa terjadi diantara kedua belah pihak atau lebih, maka peradilan menjadikan rujukan dan tempat mencari keadilan dan kebenaran. Hakim akan melihat dan menganalisis konflik maupun sengketa berdasrkan proses persindangan yang telah berlangsung. Namun terdapat penyelesaian yang tidak mengharuskan pihakpihak yang bersengketa hadir dan melalui porses persidangan yang panjang dan melakukan.

Penyelesaian sengketa dengan jalur mediasi menjadi solusi jika terjadi situasi yang kurang kondusif khususnya sengketa peradilan itu sendiri, seperti menumpuknya perkara yang harus diselesaikan.

Menurut Joni Emirzon konflik adalah adanya pertentangan atau ketidaksesuaian antar pihak yang akan dan sedang mengadakan hubungan kerja sama. Dalam pengertian lain konflik bisa di maknai sebagai suatu kondisi dimana pihak yang satu menghendaki agar pihak lain berbuat atau tidak sesuai yang di inginkan. Keberadaan konflik antar manusia juga mengilhami lahirnya keinginan untuk mengakhiri atau menyelesaiakan konflik atau perselesihan diantara mereka. ${ }^{5}$

\footnotetext{
${ }^{3}$ Hidayat Maskur, Strategi dan Taktik Mediasi (Berdasarkan Perma No. 1 Tahun 2016 Tentang Prosedur Mediasi Pengadilan), (Kencana, Jakarta, 2016), h 1.

${ }^{4}$ TakdirRahmadi, mediasi Dalam Penyelesaian Sengketa Dengan Pendekatan Mufakat, (Jakarta Raja grafindo,2011),h.1

${ }^{5}$ Hidayat Maskur, Strategi dan Taktik Mediasai (Berdasarkan Perma No. 1 Tahun 2016 Tentang Prosedur Mediasi Pengadilan), h 2.
} 
Karena itulah konteks kehidupan negara kita terdapat lembaga peradilan yang berfungsi sebagai alat negara yang bertugas menerima, memeriksa dan mengadili serta memutus perkara yang masuk dalam konteks status negara kita yang negara hukum maka sudah selaknya apabila hukum di letakkan dalam level tertinggi dalam konteks penyelesaian masalah yang telah masuk ke rana hukum.

Perkara yang masuk dan diselesaikan melalui mekanisme peradilan pada umumnya dinamakan jalur litigasi yaitu proses yang diminati masyarakat mencari keadillan yang diharapakan masyarakat agar bisa menyelesaikan sengketa secara adil menurut hukum yang berlaku. Dalam proses penyelesaian sengketa para pihak yang berperkara harus melalui tahap mediasi .

Mediasi dalam pegadilan merupakan lembaga pemberdayaan dalam perdamaian yang berlandaskan filosofi pancasila yang berdasar pada sila ke empat "kerakyatan yang dipipim

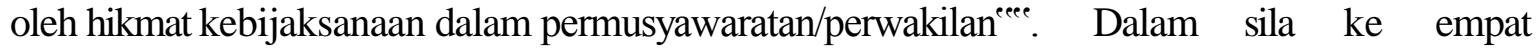
pancasila bermakna menghendaki upaya penyelesaian sengketa konflik atau perkara melalui musyawarah dan mufakat yang di dalamnya terdapat semangat kekeluargaan. Dari sini dapat ditarik kesimpulan setiap sengketa atau konflik dalam berperkara hendaknya di selesaikan melalui porsedur perdamaian.

Penyelesaian sengketa melalui dengan cara mediasi telah lama dikenal dalam praktik hukum Islam. Mediasi merupakan istilah yang di dalam Hukum Islam di sebut dengan tahkim. Tahkim berasal dari bahasa arab yang berarti penyerahan putusan pada seseorang yang menerima putusan.Selain itu tahkim juga bisa di gunakan sebagai istilah bagi orang atau kelompok yang di tuju untuk mendamaikan sengketa yang terjadi di antara kedua bela pihak di mana para pihak di beri kebebasan dalam memilih (mediator) sebagai penengah atau orang di anggap netral yang mampu mendamaikan ke dua belah pihak yang bersengketa. ${ }^{6}$

Dalam perjalanan dan perkembangan kehidupan manusia selanjutnya sampai pada abat ke 21 ini sudah banyak pola atau aturan hukum yang penyelesaian konfliknya

${ }^{6}$ M.Hasabi,Peradilan dan Hukum Acara Islam.(Jakarta :PT AL-Ma'arif 1984), h. 6. 
melibatkan pihak ke tiga sebagai penengah (mediator) yang dilakukan, mulai yang bersifat kemasyarakatan (adat), religious(agama) maupun penyelesaian secara nasional (kenegaraan).

Demikian halnya Indonesia sebagai sebuah negara yang berasas Hukum, mengenal tiga peneyelesaian sengketa, yang pertama ialah mediasi dalam sistem hukum adat, kedua mediasi dalam sistem hukum Islam dan yang ke tiga mediasi dalam hukum barat. Dalam perkembangan yang semakin kompleksnya kehidupan masyrakat indonesia, peneyelesaian secara damai (mediasi) dimasukkan dalam bagian hukum secara peradilan.

Kedudukan peradilan sebagai pelaksana kehakiman yang berperan sangat penting sebagai tempat terakhir mencari keadillan dari segala persoalan yang menyangkut pelanggaran hukum dan ketertiban masyarakat khusus dalam perkara perdata.sehingga secara teoritis masi di andalkan sebagai badan yang berfungsi dan berperan menegakkan kebenaran dan keadilan $^{5}$. Meskipun demikian kenyataan yang dihadapi masyarakat indonesia saat ini adalah ketidak efektifitasnya dalam sistem pelaksanaan peradilan .

Untuk mengatasi sistem pelaksanaan peradilan yang tidak efetif dan efesien, maka muncul alternatif penyelesaian sengketa dengan perdamaian. Dalam hukum acara,didapati pasal 130(selanjutnya di sebut HIR) maupun pasal 154(selanjutnya di sebut R.Bg)kedua pasal yang dimaksud mengenal dan menghendaki penyelesaian sengketa yang melalui cara damai.Pasal 130 ayat (1)dan(2) HIR dan upaya perdamaian yang di maksud oleh pasal 130 ayat (1)HIR bersifat imperatif. Artinya hakim ini berkewajiban mendamaikan pihak-pihak yang bersengketa sebelum memulai persidangan.dan hakim berusaha untuk mendamaikan dengan cara baik-baik agar dapat menemukan titik temu di antara kedua belapihak sehingga tdk perlu adalagi porses persidangan yang lama dan mengeluarkan biaya mahal.

Pada dasarnya keseluruhan PERMA yang dilakukan oleh Mahkamah Agung terkait prosedur mediasi merupakan suatu pengukuhan atau pengesahan untuk mengharapkan mediasi menjadi suatu instrumen yang efektif dalam menyelesaikan perkara di pengadilan tingkat pertama. Jika didasari oleh ketentuan maka upaya perdamaian di HIR dan Rbg asal mula mediasi pengadilan di indonesia bermula dari RAKERNAS 1 Mahkamah Agung pada tahun 2001, salah satu pembahasa dari RAKERNAS tersebut yakni pemberdayaan kembali pengadilan tingkat pertama dalam melakukan upaya perdamai. 
Upaya perdamaian atau mediasi yang dilakukan oleh pengadilan merupakan suatu upaya dari mahkama agung untuk mengurangi perkara- perkara yang masuk di pengadilan negeri, karena itu sering kali terjadi macet serta menumpuknya antrian perkara di pengadilan negeri. Mediasi ini dianggap dapat menyelesaikan perkara dengan cepat dan mengurangi tumpukan atau kemacetan perkara.

Jika dilihat dari sudut pandang para pihak, mediasi bermanfaat karena hasil akhir mediasi bukanlah merupakan suatu putusan menang atau kalah, melainkan kesepakatan perdamaian para pihak masing-masing pihak dapat saling diuntungkan.

Pada perkembangannya lembaga mediasi ini belum juga dapat mengupayakan damai diantara para pihak seperti yang diamanatkan oleh pancasila, hal tersebut perlu adanya suatu inovasi atau terobosan dibidang mediasi yang memfasilitasi para pihak untuk berdamai. Oleh karena itu maka muncul Mediasi Teleconference di Pengadilan Agama. Mediasi Teleconference merupakan inovasi atau gagasan dari pengadiilan agama yang merupakan mediasi yang dilakukan secara jarak jauh atau teleconference. Mediasi teleconference yang telah dicetuskan oleh pengadilan agama yang dilatar belakangi oleh wilayah hukum.

Jika dilihat pada saat pembentukan inovasi mediasi teleconference, mediasi teleconference merupakan suatu inovasi yang baru yang belum diatur oleh PERMA RI No.1 Tahun 2008, sehingga dalam kompetensi inovasi pelayanan peradilan pada Tahun 2015 mediasi teleconference ini dirumuskan pada salah satu pasal dalam PERMA RI No.1 Tahun 2016 ini menjadi payung hukum bagi pelaksanaan mediasi teleconference.

Jadi mediasi teleconference merupakan pelaksanaan mediasi yang dilakukan di ruang mediasi pengadilan yang dihadiri kuasa hukum para pihak atau tanpa dihadiri salah satu pihak, akan tetapi komunikasi mediator dan para pihak dilakukan melalui audio visual yang itu teleconference dengan memanfaatka fasilitas video call dengan berbagai applikasi teleconference.

Tujuan dari inovasi teleconference yaitu untuk membuka akses bagi para pihak yang tidak dapat dihadiri dalam pertemuan mediasi di ruang mediasi pengadilan, namun tetap dapat melakukan komunikasi dalam rangka merubahnya atau menyelesailan permasalahan melalui komunikasi audio visial. Hal ini merupakan suatu inovasi atau 
terobosan baru di Indonesia akan mempengaruhi dalam tingkat kesuksesan dan keberhasilan mediasi dalam mendamaikan para pihak.

\section{Metode Penelitian}

Jenis penelitian ini tergolong kualitatif dengan menggunakan pendekatan pustaka (Library Research), yakni suatu penelitian dengan cara menuliskan, mengklarifikasi dan menjadikan data yang diperoleh dari berbagai sumber tertulis. Adapun metode pengumpulan data yakni menggunakan tehnik dokumen (studi pustaka), mengutip dan menganalisis data dengan tekhnik dokumen yang dimaksud teknik ini untuk mengumpulkan data terkait yang dimuat dalam dokumen-dokumen berupa buku-buku, jurnal dan hasil penelitian beruapa skripsi, tesis dan disertasi.

\section{Pengertian Mediasi Secara Umum}

Secara etimologi, istilah mediasi berasal dari bahasa latin yaitu "mediare" yang berarti berada di tengah. ${ }^{7}$ Makna menunjuk pada peran pihak ketiga sebagai mediator dalam menjalankan tugasnya menengahi dan menyelesaikan sengketa para pihak juga bermakna pada posisi netral dan tidak memihak dalam meneyesaikan para pihak. Mediasi iyaitu salah satu cara yang di kembangkan saat ini yang sifatnya non ligitasi. Artinya suatu cara peneyelesaian sengketa di luar pengadilan. Menurut wahbah zulhaili,mediaisi secara Bahasa iyaitu menghentikan permusuhan atau perselisihan. Sementara menurut istilah mediasi adalah porses perjanjian untuk menghentikan permusuhan perkaitan dengan pertkaian,sengeketa,konflik, kedua belah pihak. Jadi mediasi dalam hukum Islam yaitu upaya mendamaikan orang- orang yang berselesih.

Adapun yang di maksud mediasi dalam porses negoisasi untuk memecahkan masalah melalui pihak luar yang tidak memihak dan netral yang akan berkerja dengan pihak yang bersengketa untuk membantu menumukan solusi kedua belah pihak. Dan pihak kedua yang memabantu menemuan solusi dalam menyelesaikan sengketa secara memuaskan kedua belah pihak. Pihak ketiga yang dimkasud untuk membantu penyelesaian sengketa tersebut "'mediator". Pihak ketiga mempunyai kewenangan untuk

${ }^{7}$ John Echol, Hasan Shadily. Kamus Inggris Indonesia (Cet. xxv; jakarta: gramedia pustaka utama , 2003), h 175 . 
memberi putusan terhadap sengketa tersebut, melaikan hanya berfungsi untuk membantu dan menemukan solusi terhadap para pihak yang bersengketa.

Dalam mediasi di kenal jugaporses negosiasi. Dalam porses mediasi yang digunnakan adalah nilai-nilai yang hidup pada para pihak sendiri seperti nilai hokum,agama,moral,etika,dan rasa adil, terhadap fakta-fakta yang diperoleh untuk mencapai suatu kesepakatan. Kedudukan penengah (mediator) dalam mediasi hanya sebagai pembentu para pihak untuk mencapai consensus, karena prinsipnya parah pihak sendirinya yang menentukan putusanya, bukan mediator. ${ }^{8}$

Menurut gatot, mediasi adalah upaya peneyelesaian sengketa atau konflik dengan melipatkan pihak ketiga yang netral, tidak memiliki kewenangan mengambil keputusan, membantu pihak-pihak yang bersengketa mencapai solusi atau penyelesaian yang diterima oleh kedua belah pihak. ${ }^{9}$

Menurut Retnowulan Sutantio adalah mediasi pemberian jasa baik dalam bentuk saran untuk menyelesaikan sengketa para pihak oleh seorang ahli atau beberapa ahli yang diangkat oleh para pihak sebagai mediator .Dan adapaun dalam pasal 1 ayat (7) perma Nomor 1 tahun 2008 pengertian mediasi adalah cara penyelesaikan sengketa melalui porses perundingan untuk memperoleh kesepakatan para pihak dengan dibantu oleh mediator.

Menurut Perma No.1 tahun 2016 pengertian mediasi sebagaimana diatur dalam pasal 1 ayat 1 yaitu 'Mediasi adalah cara penyelesaian sengketa melalui porses perundingan untuk memperoleh kesepakatan para pihak dengan dibantu oleh mediator', ${ }^{10}$ Di ketahui mediator sangatlah penting untuk menetukan efetifitas porsedur peneyelesian sengketa, ia harus secara layak memenuhui kualifikasi tertentu serta berpengalaman dalam komunikasi dan egosiasi agar mampu mengarahkan para pihak yang bersengketa, dan itu sangat membantu. Tetapi pengalaman apa pun, selain pengalamannya sendiri sebagai mediator, memang sangat kurang relavan. Pengetahuan secara subtansi atas permasalahan yang disengketakan tidak mutlak dilakukan ,yang lebih penting yaitu

${ }^{8}$ Sanusi Bintang dan Dahlan ,Pokok-Pokok Hukum Ekonomi dan Bisnis ,(Citra Aditya Bakti ,Bandung,2000),h,120.

${ }^{9}$ Gatot Soemartono ,Arbitrase dan Mediasi di Indonesia, (Garmedia Pustaka Utama ,Jakarta, 2006)h,

${ }^{10}$ Maskur Hidayat, Strategi dan Taktik Mediasi Berdasarkan Perma No. 1 Tahun 2016 tentang Prosedur Mediasi di Pengadilan (Jakarta; Kencana, 2016), h.53 
kemanpuan atau menganalisis dan keahlian menciptakan pendekatan pribadi. ${ }^{11}$ Di samping itu, secara tersirat dapat di jumpai pula pengaturan mediasi dari berbagai peraturan perundang-undangan. Contonya adalah undang-undang nomor 23 tahun 1997 tentang pengelolaan hidup. Di buka kesempatan untuk menggunakan cara penyelesaian sengketa lingkungan hidup di luar pegadilan. Pasal 30 UUPLH menyebutkan bahwa:

"Penyelesaian lingkungan hidup dapat ditempuh melalui pengadilan atau luar pengadilan berdasarkan pilihan secara sukarelah para pihak yang berperkara".

Selanjutnya pasal 32 menyebutkan bahwa yang dimaksud jasa pihak ketiga yang berwenang mengambil keputusan adalah mediasi. Dalam peneyelesaian dapat di ketehui penegaturan secara lebih terperinci tentang penggunaan pihak ketiga, yakni untuk melancarkan perundingan di luar pegadilan,parah pihak yang berkepentingan dapat meminta jasa ketiga yang netral yaitu yang pertama pihak ketiga netral yang tidak memiliki kewenangan mengambil keputusan. Dan pihak ketiga yang netral yang memiliki kewenangan mengambil keputusan arbiter ini bersifat tetap dan mengikat pihak yang bersengketa. $^{12}$

Dalam PP No.54 tahun 2000 ditentukan kriteria untuk menjadi mediator lembaga pelayanan penyelesaian sengketa lingkungan hidup diluar pegadilan yaitu:

a. Cakap melakukan tindakan hukum.

b. Berumur paling rendah 30 (tiga puluh) tahun.

c. Memiliki keterampilan untuk melakukan perundingan atau penegahan.

d. Memiliki pengalaman serta meneguasai secara aktif bidang lingkungan hidup paling sedikit 5 (lima)tahun.

e. Tidak ada keberatan di masyarakat (setelah di umumkan dalam jangka satu bulan)

Pemberlakuan mediasi dalam sistem perdailan di Indonesia di dasarkan dalam PERMA Nomor 1 tahun 2008 . Indonesia dapat di katakana terlambat dalam mealakukan sistem mediasi. Singapurah dengan Singapore mediatoncenter telah lahir sejak tahun 1996. Mahkama Agung sebelum mengeluarkan PERMA Nomor 1 tahun 2008 terlebih dahulu

\footnotetext{
${ }^{11}$ Abdul Halim Talli, ( Mediasi dalam PERMA Nomor 1 tahun 2008), Makassar,http://journal.uinalauddin.ac.id/index.php/alqadau/article/download/2635/2486, diakses 02 Januari 2020.

${ }^{12}$ Gatot Soemartono, Arbitrase dan Mediasi di Indonesia, (Jakarta,Pt Garmedia Pustaka Utama,2006 )h, 8.
} 
melakukan studi kahsus kepada negara-negar yang telah terlebih dahulu mempunyai sistem Mediasi,seperti negara Australia, jepang, Amerika dan negara-negara Eropa.

Dari ketentuan-ketentuan mengenai pengertian mediasi,dapat ditarik suatu kesimpulan bahwa mediasi adalah suatu porses pencarian solusi terbaik untuk membawa para pihak pada suatu kesepakatan, yang mana kesepakatan itu diperoleh dan mendapat persetujuan dari pihak-pihak yang bersengketa tanpa adanya campur tangan mediator.

\section{Efektifitas Mediasi Secara Langsung dan Mediasi Melalui Media Teleconference}

Efektivitas berasal dari kata efektif dalam bahasa inggris effective, dalam kamus Jhon M. Echols dan Shadily artinya dapat membawa berhasil dan ditaati. Dalam kamus Besar Bahasa Indonesia, efektif artinya dapat membawa hasil, berhasil guna tentang usaha atau tindakan dapat berarti sudah berlaku tentang undang-undang atau peraturan tentang mediasi dan pelaksanaan mediasi yang profesional ${ }^{13}$. Adapun secara terminologi para pakar hukum dan sosiologi hukum memberikan pendekatan tentang makna efektifitas sebuah hukum beragam, tergantung pada sudut pandang yang diambil.

Soerjono Soekanto sebagaimana dikutip oleh taraf kepatuhan warga masyarakat terhadap hukum, termasuk para penegak hukumnya. Sehingga dikenal suatu amunis, bahwa: taraf kepatuhan hukum yang tinggi merupakan suatu indikataor berfungsinya suatu sistem hukum. Dan berfungsinya hukum merupakan pertanda bahwa hukum tersebut telah mencapai tujuan hukum, yaitu berusaha untuk mempertahankan dan melindungi masyarakat dalam pergaulan hidup.

Menurut Soerjono Soekanto, efektif atau tidaknya suatu hukum ditentukan oleh beberapa faktor. Faktor-faktor ini mempunyai arti netral, sehingga dampak positif atau negatifnya terletak pada sisi faktor-faktor tersebut adalah sebaagi berikut: ${ }^{14}$

1. Faktor hukumnya sendiri (undang-undang), maksud faktor hukumnya dalam poin pertama ini menurut Soerjono Soekanto dengan undang-undang dalam arti materil adalah peraturan tertulis yang berlaku umum dan dibuat oleh penguasa pusat maupun daerah yang sah.

\footnotetext{
${ }^{13}$ Tim Penyusun Kamus Pusat Bahasa,Kamus Besar Bahasa Indonesia Edisi Ketiga, cet II,(Jakarta:Balai Pustaka,2002)h,284.

${ }^{14}$ Soerjono Soekanto, Faktor -faktor yang Mempengaruhi Penegakkan Hukum, (Jakarta:Raja Grafindo,2007) h,8
} 
2. Faktor penegak hukum, ruang lingkup dari istilah penegak hukum adalah luas sekali, oleh karena mencakup mereka yang secara langsung dan secara tidak langsung berkecimbung dibidang penegak hukum.

3. Faktor sarana atau fasilitas yang mendukung penegak hukum tampa danya sarana atau fasilitas tertentu, maka tidak mungkin menegakkan hukum akan berlangsung dengan lancar. Sarana atau fasilitas tersebut antara lain mencakup tenaga manusia yang berpendidikan dan terampil, organisasi yang baik, peralatan yang memadai, keungan yang cukup, dan seterusnya. Kalau hal-hal itu tidak terpenuhi maka mustahilah penegak hukum akan tercapai tujuannya.

Lembaga peradilan sebagai institusi yang diciptakan sebagai sistem hukum dengan fungsi sebagai sarana penyelesaian sengketa yang adil melalui proses peradilan yang sederhana, cepat dan biaya ringan. Asas-asas bahwa proses peradilan dilaksanakan secara sederhana, cepat, dan biaya ringan diwujudkan dalam pencapaian peradilan yang efektif itas dan efesien. Namun implikasi pesatnya perkembangan kegiatan ekonomi dan bisnis tidak diimbangi dengan lembaga peradilan sebagai sarana penyelesaian sengketa yang diharapkan masyarakat. Hal ini dikarenakan lembaga peradilan yang secar konkrit mengembang tugas untuk menekankan hukum dan keadilan ketika menerima, memeriksa, mengadili, serta menyelesaikan setiap sengketa yang diwujudkan, dianggap sebagai tempat penyelesaian sengketa yang tidak efektif dan efesien.

Pelaksanaan mediasi di pengadilan agama mengacu pada perma No. Tahun 2008 yang kemudian di revisi dengan PERMA No.1 2016 yang mengatur tentang prosedur mediasi di pengadilan. PERMA No. 1 Tahun 2016 tentang mediasi di pengadilan memiliki kekuatan mengikat dan daya paksa bagi para pihak yang berperkara di pengadilan, karena bila tidak melaksanakan mediasi, maka keputusan pengadilan batal demi hukum. Setiap peaksanaan perkara perdata di pengadilan harus di upayakan perdamaian dan mediasi sendiri merupakan kepanjangan upaya perdamaian. Mediasi akan menjembatangi para pihak dalam menyelesaikan masalah yang buntu agar mencapai dan memperoleh solusi terbaik.

Sampai saat ini pengadilan masih dipercaya masyarakat sebagai lembaga untuk menyelesaikan sengketa. Keberadaan lembaga peradilan merupakan suatu lembaga yang 
berfungsi untuk mengkordinasi sengketa-sengketa yang terjadi dalam masyarakat mencari keadilan yang mempercayai jalur letigasi.

Medisi dipengadilan dalam berbagai negara sudah dikembangkan, yang salah satu tujuan adalah dalam rangka pemeriksaan akses keadilan bagi warga negara, penghematan biaya dan lain-lain. Dalam mewujudkan tujuan peradilan yang sederhana cepat dan biaya ringan melalui lembaga pengadilan yang efektifitas dan efesien, mahkamah agung sebagai penyelenggara peradilan tertinggi di Indonesia mulai menggagas beberapa metode untuk mempersingkat proses penyelesaian sengketa di pengadilan. Salah satu gagasan yang cukup progresif antara lain pengintegrasian mediasi di pengadilan.

Porses penyelesaian perkara melaui mediasi melalui porses litigasi [pengadilan] cenederum menghasilkan masalah baru karnah sifatnya yang win-lose, penyelesian sengketa di luar pengadilan. Mediasi merupakan salah satu cara meneyesaian perkara winwin solution.

Mediais merupakan suatu porsedur penegahan di mana sesuatu seseorang pertindak sebagai penegah untuk perkomunikasi antara parah pihak yang berperkara, sehingah berbeda atas perkara tersebut dapat di pahami dapat didamaikan. Mediasi yang melahirkan akan menjadi penyesaian yang tuntas karnah hasil akhirnya tidak mengunakan prinsip win or lose. Penyelesaian dengan porses mediasi banyak memeberikan manfaat parah pihak, waktu yang di temput akan menekan biyaya lebih murah, dipandang dari segi emosional penyelesaian dengan mediasi dapat memberikan kenyamanan dari para pihak, karena butirbutir kesepakatan dibuat sendiri oleh para pihak sesuai dengan kehendaknya. Mediasi pada dasarnya sudah ada sejak dulu, karena sistem penyelesaian perkara masyarakat pada umumnya menggunakan prinsip mediasi.

Mediasi merupakan proses penyelesaian non litigasi, ada dua jenis mediasi yaitu diluar dan didalam pengadilan. Mediasi yang dilakukan diluar pengadilan diatur dengan undang-undang No. 30 tahun 1999 tentang arbitrase dan alternatif penyelesaian perkara, dan mediasi yang dilakukan dalam pengadilan diatur dalam PERMA No.1 Tahun 2016 tentang prosedur mediasi di pengadilan.

Beberapa hal yang menjadi dasar bahwa ada faktor yang mempengaruhi tingkat keberhasilan mediasi dipengadilan, karena sejak diberikan aturan yang jelas tentang proses 
mediasi dipengadilan dari tahun ke tahun, tetapi juga tidak memnberikan dampak mencatau manfaat yang nyata, sehingga penulis melihat bahwa muncul sebuah asumsi adanya tidak sesuai antara teori dan praktek ataupun adanya ketidaksesuain antara das sollen dan das sein, banyak faktoral tersebut juga dapat dilihat dalam mencapai kesepakatan. Meskipun banyak sisi manfaat dari proses perdamaian dengan cara mediasi, namun pada kenyataannya tingkat keberhasilan lembaga mediasi dpengadilan masih sangat rendah.

Evetifitas mediasi dalam perkara di ukur dari terjadinya pencaputan gugatan oleh pengugat. Ketentuan ini sangat sulit di penuhi dalam penyelesaian perkara melalui mediasi. Penyelesaian perkara melalui mediasi penyelesaian perkara yang di lakukan dengan cara damai dan tidak mendapatkan jalan keluar. Ukuran keberhasilan mediasi seperti ini kurang sejalan dengan prinsip-prinsip yang di kembang dalam ilmu mediasi. Stndar keberhasil mediasi harus di ukur dari kesepakatan damai yang di sepakati oleh pengugat dan tergugat.

\section{Pandangan Ulama Mazhab Tentang Mediasi Media Teleconference}

Dalam hukum Islam penyelesaian sengketa melalui cara mediasi telah lama di kenal. Hukum islam yang dimaksud di sini adalah hukum yang sumbernya dari wahyu Allah. Penegasan ini di maksudkan untuk membedakan hukum lainya yang sumbernya bukan wahyu dari Allah, yang sumbernya dari pemikiran manusia. Karena itu, hukum Islam tidak terbatas pada hukum yang diberlakukan dinegara-negara yang berada dikawasan Timur Tengah, tetapi juga yang berlaku di negara yang ada diluar kawasan tersebut, yakni negeri-negeri muslim seperti di Indonesia, Malaysia, Brunei dan lainnya.

Tahkim sebenarnya telah dipraktikan sejak masa awal Islam.Rasulullah sendiri telah mempraktikannya, misalnya ketika Rasulullah Saw menerima putusan Sa'ad ibn Muadz mengenai bani quraidhah. Demikian juga pertengkatran antara Umar bin Khattab Raden ubay ibnu Ka'ab tentang kebun kurma, yang perkaranya ditahkimkan oleh Sa'id bin Tasbit. Semua sahabat sepakat menerima keputusan hakam dan membenarkannya. Praktik penyelesaian sengketa melalui tahkim diabadikan dalam Q.S an-Nisa/ 4:35 dan 128.

Menurut Prof. Dr. Syahrizal Abbas Rasulullah Saw telah melakukan praktik mediasi pada peristiwa terletak kembali Hajar Aswad dan perjanjian Hudaibiyah. Kedua 
peristiwa tersebut memiliki nilai dan srategi dan resolusi konflik dan negoisasi, sehingga kedua peristiwa ini memiliki perspektif yang sama yaitu mewujudkan perdamaian.Nilai positif yang dapat dipetik dari peristiwa tersebut adalah berupa kesabaran, penghormatan, dan penghargaan terhadap kemanusiaan, berbagi bersama, komitmen, proaktif, dan prokreatif, berfikir untuk menyelesaikan sengketa.Nilai tersebut penting artinya dikualisasikan mediator dan para pihak yang terlibat dalam penyelesaian sengketa (konflik), baik antara individu maupun antara kelompok dalam masyarakat.

Menurut Imam Syafi'i,dalam Q.S al-nisa ayat 35 bermakna wajib, untuk menghindari kemudaratan ${ }^{15}$. Oleh karena itu kedudukan (pengangangkatan) hakam dalam perkara syikak (perselisihan suami istri) untuk menghindari adanya percekcokan yang berlarut-larut adalah wajib, untuk mencapai kemaslahatan.

Adapun wewenang hakam dalam perkara syikak menurut mazhab Hanafi. Hakam tidak berhak menceraikan, kecuali dengan kerelaan suami isteri, sebab hakam hanya berstatus sebagai wakil suami isteri. Karena itu adapun keputusan yang di ambil harus mendapat persetujuan suami isteri. ${ }^{16}$ Di sebabkan kewenanganya yang demikian , makna tidak boleh menjatuhkan talak, karena suami tidak mewakili pekerjaan itu kepadanya, caranya yaitu hakam melaporkan hasil pekerjaanya kepada hakim. Sesudah hakim mempertimbangkan sepenuhnya dan teryata mereka harus cerai, dikerenakan hal memerintahkan hakam untuk menceraikan mereka. ${ }^{17}$

Alasan mazhab hanafi yaitu sensungguhnya Allah SWT tidak menyerahkan kepada kedua hakam ini melaikan hanya untuk mengishlahkan, sebagaiaman firman Allah SWT: (jika kedua orang hakam memberi taufik) yang menunjukan bahwa diluar tugas tidak ada . dan keduanya (hakam) berstatus sebagaiaman wakil, sehingga mereka tidak mungkin melaksanakan keputusannya, melaikan harus kerelaan yang memberi wakil.

Imam malik dalam bukunya al-Muwaththa mengemukakan peran dalam masalah syikak peristiwa yang terjadi saat Ali bin Abi Thalib dalam menyelesaikan perselihan suami isteri, yang sepenunya diserahkan kepada dua orang hakam untuk mengatasi

\footnotetext{
${ }^{15}$ Muhammad 'Ali al- Sabuni, Rawa'i al_Bayan Tafsir ayat al - Ahkam Min al-Qur'an ,(Jakarta : Dar al Islamiyyah), h, 337

${ }^{16}$ Muhammad Ali al- Sabuni, Rawa'i al- Bayan Tafsir ayat al-Ahkam Min al-Qur'an, h,471.

${ }^{17}$ Muhammad bin Ahmad al- Anshari al-Qurthubi , Ahkam al- Qur'an. (Mesir ;Dar al- Kitab al- Arabi, 1967,) \mathrm{h}, 176$
} 
kejadian tersebut, juga firman Allah SWT dalam surat al- nisa (4):35, mengenai wewenang hakam dalam perkara syikak imam Malik berpendapat bahwa kewenangan hakam adalah memisahkan atau mengumupulkan kembali suami isteri.

Menurut Mazhab Maliki beserta murid- muridnya, kedua hakam bisa mengadakan pemisahan atau pengumpulan antara suami isteri tanpa memerlukan izin dan pemberian kuasa atau persetujuan suami isteri. Alasan mereka ialah riwayat yang diterima dari 'Ali bin Abi Thalib, bahwa ia mengatakan kepada kedua hakam tersebut dengan :dalam hal ini imam malik mempersamakan hakam tersebut dengan penguasa. Sedangkan penguasa bisa menjatuhkan talak karena ada tindakan yang merugikan, jika hal itu sudah nyata.

Pendapat di atas mempnyai alasan bahwa hakam sebagaimana dinyatakan dalam Al- Qur'an itu jelas bukan wakil suami isteri. Sebab yang perintahkan mengangkat hakam bukan suami isteri yang bersangkutan, akan tetapi penguasa (ulul amri), dalam hal ini adalah pengadilan. Oleh karena itu, kekuasaan hakam untuk mengambil keputusan untuk melangsungkan perkawinan atau menceraikan suami istri, telah memperoleh kekuatan dari ulul amri (penguasa). Khalifah utsman pernah mengangkat ibnu abbas dan mu'awiyah untuk bertindak sebagai hakam antar iqbal bin abi thalib dan istrinya fatimah binti hatabah dengan memberi kekuasaan penuh, apabilah mereka mempertimbangkan yang lebih maslahat adalah menceraikan antara suam istri maka hendaklah mereka menceraikan. Khalifah ali juga pernah melakukan hal yang sama, memberikan kekuasaan yang penuh kepada hakam yang di angkat untuk mengambil keputusan mana yang lebih maslahat, melangsungkan perkawinan atau menghentikannya.

Pendapat di atas menjelaskan bahwa hal tersebut lebih memberikan tanggung jawab kepada para hakam agar benar-benar bekerja dan mempertimbangkan maslah yang telah di hadapi sehingga dalam pengambilan keputusan benar-benar dengan pertimbangan yang matang, dilihat dari beberapa segi kemungkinan-kemungkinan yang akan terjadi secara komperensif. Sehingga apa yang telah diputuskan oleh hakam tinggal di kuatkan oleh pengadilan, dengan demikian perselisihan yang terjadi antara suamo istri, apabilah telah berakhir dengan perceraian akan segera menyelamatkan suami istri dari penderitaanpeneritaan batin (psikologis) yang tidak menguntungkan dalam hubungan perkawina mereka. 
Landasan filosofi tentang penyelesaian konflik melalui mediasi pernah dilaksanakan oleh rasulullah Saw baik sebelum menjadi rasul maupunsetelah diangkat menjadi rasul. Proses penyelesaian konflik (sengketa) dapat ditemukan dalam peristiwa perjanjian Hudabiyah. Kejadian ini merupakan konflik yang potensial mengarah kepada kekerasan dan pertumphan darah. Peristiwa ini terjadi ketika nabi Muhammad Saw kembali ke mekah sebagai pemenang dan pemimpin politik yang berkuasa,setelah dipertemukan setelah bermukmin di Madinah setelah hijrah di Mekah nilai dan strategi penyelesaian sengketa dapat diidentifikasi dari tindakan nabi Muhammad Saw pada peristiwa ini yaitu sikap beliau sebsgsi pemimpin politik yang sedang berkuasa menanamkan sikap negoisasi, kompromi, memposisikan sama para pihak serta menghargai kesepakatan. Nabi Muhammad Saw telah melakukan negoisasi dengan pimpinan kaum kafir Qurais agar mereka bersedia dengan kaum muslimin yang diwakili oleh nabi Muhammad Saw telah berusaha meyakinkan kaum kafir Qurais agar bersedia duduk di satu meja dengan kaum muslimin, walaupun sebelumnya kedua kelompok ini saling berkait. Dalam mediasi kemampuan meyakinkan para pihak yang bersengketa untuk bersedia duduk bersama merupakan langkah yang menentukan keberhasilan proses mediasi selanjutnya.

Penyelesaian sengketa peletakan kembali Hajar Aswad dalam pembangunan kembali ka'bah dilakukan oleh nabi Muhammad Saw dikala itu belum memiliki kekuasaan politik di Mekah.Nilai positif yang dapat diambil dari peristiwa tersebut adlah berupa kesabaran, penghormatan, komitmen, proaktif, dan kreatif, befikir untuk penyelesaian sengketa.Nilai tersebut penting artinya dikualisasikan, mediator dan para pihak yang terlibat dalam menyelesaikan sengketa (konflik) baik antara individu maupun antara kelompok dalam masyarakat.

Kedua peristiwa ini dikenal baik oleh kaum muslimin diseluruh dunia, dan karena itu diterima secara umum. Peletakan kembali hajar aswad dan perjanjian Hudaibiyah memiliki nilai dan strategi resolusi konflik (sengketa) terutama mediasi dan negoisasi, sehingga kedua peristiwa ini memiliki perspektif yang sama yaitu mewujudkan perdamaian.

Konsep Islam dalam memahami persengketaan selalu berttujuan untuk menciptakan perdamaian.Oleh karena itu, Islam selalu memerintahkan kepada pemeluknya 
agar selalu berusaha menghindari konflik, namun bila terjadi, perdamaian adalah jalan yang utama yang harus diambil selama tidak melanggar syariat.

Penerapan prinsip perdamaian dalam syariat Islam dapat dilakukan terhadap seleruh sengketa baik sengketa politik, ekonomi, hukum, sosial dan lain-lain.Rasulullah hanya menegaskan bahwa perdamaian tidak boleh dilakukan jika bertujuan untuk menghalakan yang haram atau mengharamkan yang halal.Itulah batas yang diberikan Rasulullah terhadap sengleta yang dapat diajukan melalui upaya damai.Namaun, secara teknis dalam kasus hukum, tidak semua perkara yang diajukan kepengadilan dapat diselesaikan melalui jalur damai. Perkara atau sengketa yang dapat ditempuh menyelesaikan melalui jalur perdamaian adalah perkara yang didalamnya mengandung hak manusia dan bukan perkara yang menyangkut hak Allah dalam kategorisasi hukum, perkara atau sengketa, yang dapat diajukan upaya perdamaian adalah perkara yang berkaiatan hukum privat, terutama yang berkaitan dengan harta dan keluarga. Sedangkan perkara dalam dimensi hukum publik atau perkatra pidana tidak dapat dilakukan upaya damai karena ada hak Allah yang terdapat secra murni didalamnya.

\section{Kesimpulan}

Pasal 1 ayat (7) perma Nomor 1 tahun 2008 pengertian mediasi adalah cara penyelesaikan sengketa melalui porses perundingan untuk memperoleh kesepakatan para pihak dengan dibantu oleh mediator.. Dalam pelaksanaan mediasi perlu ada yang namnaya mediator atau dalam hukum Islam dikenal sebagai Hakam. Menurut Imam Abu Hanafi, Imam al-Syafi'I dalam salah satupendapatnya, dan imam Ahmad dalam satu riwayat, berependapat bahwa hakam adalah orang yang mendapatkan kepercayaan (wali). Sementara menurut penuduk Madinah, Imam Malik, imam Syafi'I dalam pendapatnya yang lain menyebut bahwa hakam adalah dua orang hakim.Menurut al-Mawardi, salah satu ulama mazhab Syafi'I, meneyebutkan makna hakam masi diperedepatkan parah ulama. Penyelesaian sengketa melalui mediasi dan alternatif penyelesaian sengketa untuk pertama kalinya diakui dan diatur dalam Undang-undang No.48 Tahun 2009 tentang Kekuasaan Kehakiman (Bab xii) sebatas persengketaan keperdataan, membutuhkan perubahan terhadap Undang-undang No.30 tahun 1999 yang lebih banyak mengatur arbitrase dibandinfkan alternatif penyelesaian sengketa. Perubahan dimaksud hendaknya sejalan 
pula dengan perubahan dalam Hukum Acara Perdata. Perlu penyelesaian sengketa melalui mediasi untuk mencapai kesepakatan bersama diantara para pihak, selain menutup kemungikinan menumpuknya berkas perkara dipengadilan, juga dapat dijadikan saran dalam memecahkan persengketaan secara damai yang diterima dan mengikat para pihak yang bersengketa.

\section{Daftar Pustaka}

Dahlan, Bintang Sanusi, Pokok-Pokok Hukum Ekonomi dan Bisnis ,(Bandung: Citra Aditya Bakti, 2000)

Echol John, Hasan Shadily. Kamus Inggris Indonesia (Cet. xxv; jakarta: gramedia pustaka utama, 2003)

Hasabi M.Peradilan dan Hukum Acara Islam.(Jakarta :PT AL-Ma'arif 1984)

Hidayat Maskur, Strategi dan Taktik Mediasi Berdasarkan Perma No. 1 Tahun 2016 tentang Prosedur Mediasi di Pengadilan (Jakarta; Kencana, 2016)

Hidayat Maskur, Strategi dan Taktik Mediasi Berdasarkan Perma No. 1 Tahun 2016 tentang Prosedur Mediasi di Pengadilan (Jakarta; Kencana, 2016)

Kementrian Agama RI, Al-Qur'an dan Terjemahnya (Jakarta: CV. Penerbit Diponegoro, 2010)

M.Yahya Harahap, Hukum Acara Perdata Tentang Gugatan Persidangan,Penyitaa Pembuktian Dan Putusan Pegadilan. (Jakarta: cet II, Sinar Grafika)

Muhammad 'Ali al- Sabuni, Rawa'i al_Bayan Tafsir ayat al - Ahkam Min al-Qur'an ,(Jakarta : Dar al - Islamiyyah)

Muhammad Ali al- Sabuni, Rawa'i al- Bayan Tafsir ayat al-Ahkam Min al-Qur'an

Muhammad bin Ahmad al- Anshari al-Qurthubi, Ahkam al- Qur'an. (Mesir ;Dar al- Kitab al- Arabi, 1967,)

Rahmadi Takdir, mediasi penyelesaian sengketa melalaui penedekatan mufakat, (Jakarta: Raja grafinda, 2011)

Soekanto Soerjono, Faktor -faktor yang Mempengaruhi Penegakkan Hukum, (Jakarta:Raja Grafindo,2007)

Soemartono Gatot, Arbitrase dan Mediasi di Indonesia, (Garmedia Pustaka Utama,Jakarta, 2006)

Soemartono Gatot, Arbitrase dan Mediasi di Indonesia, (Jakarta,Pt Garmedia Pustaka Utama,2006 )

Talli Halim Abdul,( Mediasi dalam PERMA Nomor 1 tahun 2008), Makassar ,http://journal.uinalauddin.ac.id/index.php/alqadau/article/download/2635/2486, diakses 02 Januari 2020.

Tim Penyusun Kamus Pusat Bahasa,Kamus Besar Bahasa Indonesia Edisi Ketiga, cet II,(Jakarta:Balai Pustaka,2002)

Naro, Wahyuddin, Abdul Syatar, Muhammad Majdy Amiruddin, Islamul Haq, Achmad Abubakar, and Chaerul Risal. "Shariah Assessment Toward the Prosecution of Cybercrime in Indonesia." International Journal of Criminology and Sociology 9 (2020): 572-86. https://doi.org/https://doi.org/10.6000/1929-4409.2020.09.5.

Syatar, Abdul, and Achmad Abubakar. Filosofi 'Uqubah Islamiyah Versi Ramadhan Al-Buti; 
Relevansi Dengan Pemidanaan Dalam Sistem Hukum Indonesia. Gowa: Alauddin University Press, 2020. 